\title{
The evolution of water trust funds in Ecuador
}

\author{
C. M. Kauffman ${ }^{1} \&$ M. Echavarría ${ }^{2}$ \\ ${ }^{1}$ Department of Political Science, University of Oregon, USA \\ ${ }^{2}$ EcoDecisión, Ecuador
}

\begin{abstract}
In early 2000 the city of Quito, Ecuador, established the Water Protection Fund (FONAG) to provide sustainable financing for the management and conservation of surrounding watersheds. FONAG was innovative in that it pioneered the use of trust funds in a voluntary, decentralized mechanism for financing watershed conservation. Since then, at least 15 similar water funds have been created or are under development in the Northern Andes, seven of which are in Ecuador. Ecuador's later water funds share many similarities with FONAG, but there are also important differences. This paper analyzes the evolution of Ecuador's water trust funds since the creation of FONAG and related changes in community-level watershed management. It does so by comparing the development and effects-todate of two of the most-recent Ecuadorian water funds: the Fund for Páramo Management and Fight Against Poverty in Tungurahua (FMPLPT) and the Regional Water Fund (FORAGUA). After defining the water trust fund model, the paper provides an overview of the FMPLPT and FORAGUA. It then compares these newer funds with FONAG to identify several trends in the financing of watershed conservation within Ecuador.

Keywords: conservation, ecosystem services, Ecuador, FORAGUA, Tungurahua, watershed management, water trust funds.
\end{abstract}

\section{Introduction}

In early 2000 the city of Quito, Ecuador, established the Water Protection Fund (Fondo para la Protección del Agua - FONAG) to provide sustainable financing for the management and conservation of surrounding watersheds. FONAG was innovative in that it pioneered the use of trust funds in a voluntary, decentralized mechanism for financing watershed conservation. Since then, at least 15 similar 
water funds have been created or are under development in the Northern Andes, seven of which are in Ecuador [1, 2].

Ecuador's later water funds share many similarities with FONAG, but there are also important differences, resulting from learning and varied social and political contexts. This paper analyzes the evolution of Ecuador's water trust funds since the creation of FONAG and related changes in community-level watershed management. It does so by comparing the development and effects-todate of two of the most-recent Ecuadorian water funds: the Fund for Páramo Management and Fight Against Poverty in Tungurahua (FMPLPT) and the Regional Water Fund (FORAGUA). After defining the water trust fund model, the paper provides an overview of the FMPLPT and FORAGUA. It then compares these newer funds with FONAG to identify several trends in the financing of watershed conservation within Ecuador.

\section{Ecuador's recent water trust funds}

Water trust funds are one of many varieties of payment for ecosystem services (PES) schemes focusing on watershed ecosystem services. The benefits that people receive from watershed ecosystems include various natural processes that affect the quantity and quality of water, as well as recreational and cultural benefits. In Ecuador, for example, forests and páramos (high altitude grasslands) serve as collectors and regulators of water flow and prevent soil erosion that damages water quality. These watershed services link the conservation and sustainable use of forests and páramos with the quantity and quality of water available to communities downstream. Water funds are like other PES schemes in that those who benefit from watershed ecosystem services (e.g., water users) pay to help ensure these services continue. This money is used for a variety of watershed management activities, including compensation to "suppliers" (e.g., communities living in catchment areas) who work to maintain clean, consistent water supplies.

However, water funds have a number of distinct features. Most importantly, they are managed as trusts by independent financial institutions, which invest these funds' assets and distribute payments to recipients (usually watershed stakeholders who improve their management practices and/or assist with conservation). Spending decisions are made by the fund's board of directors, a public-private body comprised mainly of the water users that contribute to the fund. In some cases, non-contributing stakeholders are also represented. Water funds are contractual arrangements that define member relations and fund use. Board members assign a technical committee responsible for organizing meetings and implementing decisions. Funds are capitalized through regular contributions from watershed service users, including public agencies (e.g., water utilities), private companies (e.g., hydroelectric companies or agricultural associations), as well as citizens that contribute through their water bill, taxes, or other programs. Additional contributions may come from external donors, such as private foundations and multilateral donor agencies. Watershed management and conservation activities are financed by interest from the trust, as well as 
additional contributions by water users and external donors. Sometimes, a portion of the trust itself is used to pay for projects.

In sum, water funds provide a sustainable funding source for watershed conservation that is independently managed for long-term benefits (e.g., the contracts for FONAG and FORAGUA are for 80 years). This contrasts with other payment for watershed services schemes that use direct transfers between water service users and providers or a bank account managed by one of the watershed's stakeholders, such as the municipal government. The independence, contractual arrangement, sustainable revenue stream, and long-term horizon provide a level of political and financial security lacking in other PES schemes. In addition, water funds provide an institutional space linking a wide variety of stakeholders (e.g. local communities, public agencies, and private corporations) that facilitates collaborative decision-making and project implementation.

\subsection{The Fund for Páramo Management and Fight Against Poverty in Tungurahua}

The Fund for Páramo Management and Fight Against Poverty in Tungurahua (Fondo de Páramos Tungurahua y Lucha Contra la Pobreza - FMPLPT) was legally created in June 2008. The fund's purpose is to improve the quantity and quality of water provided to Tungurahua province by its watersheds. As the name implies, the strategy is to finance and promote projects to conserve the páramo ecosystems where water collects while simultaneously improving local populations' standard of living through economic and production projects. The fund has seven original members: Tungurahua's provincial government, EMAPA-A (the municipal water company for Ambato, the capital city), two hydroelectric companies (HIDROAGOYAN and HIDROPASTAZA), and the province's three indigenous movements (MIT, MITA and AIET), which represent the communities living in the páramos. In October 2011 the Ambato regional electric company also joined.

The fund is capitalized with annual voluntary contributions from its eight partners, who serve on the board of directors. The German Technical Cooperation Agency GTZ (now GIZ) has contributed money on behalf of the three indigenous movements to ensure indigenous communities are represented on the board. In the fund's first four years (2008-2011), member contributions averaged $\$ 485,000$ per year (see Table 1). Sixty percent of these contributions are invested to grow the fund, while 40 percent (averaging $\$ 194,000$ per year) go toward financing projects defined in annual operating plans [3]. Projects are also financed by interest from the trust's investments and special donations from organizations such as GIZ, the US Agency for International Development, FONAG, and others. As the trust has grown, so have its interest payments, from $\$ 29,947$ in 2009 to $\$ 57,337$ in 2011 [3]. Special donations vary by project and totaled $\$ 252,857$ between 2008 and 2011 .

The fund's technical secretariat, appointed by the board, creates the annual operating plans. These determine the projects financed each year. Funding decisions are made in accordance with the trust's contract, its strategic institutional plan (created in July 2010 through a participatory process), 
Tungurahua's Provincial Development Agenda, and participatory budgeting documents collectively created by social organizations through the province's Water Parliament (described below). Priority is given to financing páramo management plans that were created at the community level and coordinated by the province's three indigenous movements, with assistance from the provincial government, local and international NGOs, and international development agencies (particularly GIZ) [4].

Table 1: Annual partner contributions to Tungurahua's water trust fund (\$US).

\begin{tabular}{|c|c|c|c|c||c|}
\hline Partner & $\mathbf{2 0 0 8}$ & $\mathbf{2 0 0 9}$ & $\mathbf{2 0 1 0}$ & $\mathbf{2 0 1 1}$ & Total \\
\hline \hline $\begin{array}{c}\text { Provincial } \\
\text { Government }\end{array}$ & 300,000 & 300,000 & 300,000 & 300,000 & $1,200,000$ \\
\hline HIDROAGOYAN & 50,000 & 100,000 & 100,000 & 100,000 & 350,000 \\
\hline EMAPA-A & 50,000 & 50,000 & 50,000 & 50,000 & 200,000 \\
\hline HIDROPASTAZA & 50,000 & 50,000 & 0 & 0 & 100,000 \\
\hline Indigenous & 10,000 & 10,000 & 10,000 & 10,000 & 40,000 \\
\hline Electric company & & & & 50,000 & 50,000 \\
\hline \hline Total per year & $\mathbf{4 6 0 , 0 0 0}$ & $\mathbf{5 1 0 , 0 0 0}$ & $\mathbf{4 6 0 , 0 0 0}$ & $\mathbf{5 1 0 , 0 0 0}$ & $\mathbf{1 , 9 4 0 , 0 0 0}$ \\
\hline
\end{tabular}

Source: Rojas [3].

The FMPLPT also finances eight programs meant to complement the community páramo management plans. These include: (1) "Communication and inter-institutional relations" (for institutional strengthening; promoting the fund; and recruiting new members and donations); (2) "Training" (to strengthen the technical capacity of professionals and community members working to conserve páramo ecosystems); (3) "Environmental education" (to create a culture of environmental protection); (4) "Intercultural programs" (to ensure respect for diverse cultural traditions and thought regarding water and páramo management); (5) "Monitoring of environmental and socio-economic variables" (to gather the scientific information necessary to make effective decisions); (6) "Production and economic revitalization" (to improve local communities' economic opportunities and create ecologically friendly production processes); (7) "Conservation of protected areas" (to improve monitoring and enforcement of Llanganates National Park); and (8) "Climate change adaptation" (to evaluate future risks and vulnerability in the province) [3].

In 2008, expenditures focused on building the fund's infrastructure and financing the only two completed páramo management plans. While communities were formulating additional plans, the FMPLPT focused on institutional strengthening and the complementary programs described above. By 2010, nine páramo management plans existed and received funding. A tenth plan was added in 2012 [4]. Over time, funding has shifted away from administrative expenses and complementary programs toward the páramo management plans. 
Table 2: $\quad$ Annual expenditures for Tungurahua's water fund (\$US).

\begin{tabular}{|l|c|c|c|c||c|c|}
\hline \multicolumn{1}{|c|}{ Expenditure } & $\mathbf{2 0 0 8}$ & $\mathbf{2 0 0 9}$ & $\mathbf{2 0 1 0}$ & $\mathbf{2 0 1 1}$ & Total & Percent \\
\hline \hline $\begin{array}{l}\text { Páramo } \\
\text { Management } \\
\text { Plans }\end{array}$ & 11,200 & 39,200 & 71,634 & 103,760 & 225,794 & $32.3 \%$ \\
\hline $\begin{array}{l}\text { Other } \\
\text { Conservation }\end{array}$ & 0 & 5,900 & 59,322 & 66,037 & 131,259 & $18.8 \%$ \\
\hline $\begin{array}{l}\text { Complementary } \\
\text { Programs }\end{array}$ & 0 & 74,369 & 60,122 & 64,318 & 198,809 & $28.5 \%$ \\
\hline $\begin{array}{l}\text { Administrative } \\
\text { Expenses }\end{array}$ & 4,275 & 45,113 & 57,634 & 35,610 & 142,632 & $20.4 \%$ \\
\hline \hline \multicolumn{1}{|c|}{ Total } & 15,475 & 164,582 & 248,712 & 269,725 & 698,494 & $100 \%$ \\
\hline
\end{tabular}

Source: Rojas [3].

By 2012, roughly 85 percent of expenses went toward financing these community-designed plans (which include projects to improve agricultural production), conservation, and environmental education, with 10 percent going toward administrative expenses and 5 percent toward financial capitalization [4].

Tungurahua's water fund has already achieved significant results. By the end of 2011, 17,635 hectares of páramo were being conserved and restored for the first time through community agreements. Anecdotal evidence suggests some improvement in vegetation and water quality. In the páramos of Yanahurco, for example, natural vegetation is returning in 80 percent of the territory. Analysis using the Water Quality Index (WQI) shows water quality has increased from 0.60 to 0.71 [4]. A network of 20 hydrometeorological stations is being installed to better evaluate changes in the quality and quantity of water. In terms of socioeconomic effects, more than 2,000 community members have been trained in conservation, sustainable agriculture and irrigation, the social management of water, páramo management, and economic management. Nearly 2,200 families have benefited from economic and production assistance [3, 4]. Perhaps the biggest changes are the improved social capacity and commitment to sustainable watershed management seen in the province, demonstrated by the community development and implementation of páramo management plans.

\subsection{The Regional Water Fund (FORAGUA)}

Legally constituted on July 8, 2009, the Regional Water Fund (Fondo Regional del Agua), or FORAGUA, is Ecuador's newest water trust fund. It is also the country's first regional fund, created to conserve, restore and protect the biodiversity and ecosystem services provided in three southern provinces: Loja, Zamora Chinchipe, and El Oro. FORAGUA's origin and institutional structure are somewhat different from FONAG and other funds promoted by The Nature Conservancy. FORAGUA was formed by international NGO Nature and Culture International (NCI) and five municipal governments: Loja, Celica, Puyango, 
Pindál, and Macará. A sixth municipal government, Chinchipe, joined in July 2011. A seventh government, Zamora, began the membership process but has yet to fulfill the requirements. Several additional governments have expressed interest. Ultimately, FORAGUA hopes to include all 37 municipal governments in Ecuador's Region 7.

FORAGUA is highly decentralized and is designed to give local stakeholders control over local watershed management policies. Each municipal government creates its own ordinances that establish municipal reserves and a fee on water use to finance local conservation and restoration projects. Municipal governments collect this fee monthly and transfer this money to the trust, which is independently managed by the National Financial Corporation (Corporación Financiera Nacional). Ten percent of the money is used for FORAGUA's administrative expenses, including the Technical Secretariat's operating budget. The remaining ninety percent is used for local watershed management programs. Each municipal government prepares an annual investment plan, in coordination with FORAGUA's technical staff. The trust releases money to each municipal government as needed to finance activities outlined in these plans. According to the trust's contract, funds may only be used for the conservation and restoration of natural vegetation; reforestation with native species; infrastructure to protect watersheds (e.g., wire and live fences); scientific investigation; monitoring and control; environmental education; and other activities permitted in municipal reserves as outlined in municipal ordinances. Municipal governments must provide receipts to ensure funds are only used for approved activities.

To capitalize FORAGUA, municipal governments initially transferred the assets from their individual payment for ecosystem services programs. These assets represented the money collected to date from the environmental fees levied on water use minus the amount already spent on conservation projects. These transfers included $\$ 240,000$ from Loja, \$11,263 from Celica, \$48,146 from Puyango, and $\$ 3,351$ from Pindal [5]. NCI contributed $\$ 229,500$ and transferred the titles of the land they had purchased for conservation. Macará has promised $\$ 50,000$, which it expects to provide in 2012 now that its ordinances are in place [6]. In total, FORAGUA was constituted with $\$ 582,150$. This money is invested in financial markets and held for emergencies. One role of the Technical Secretariat is to grow the fund by recruiting additional contributions from national and international partners, both public and private.

Subsequent member contributions have come in the form of monthly transfers of the environmental fees each municipality collects from water users. In contrast to FONAG and the FLMPLT, these monthly contributions are not used to further capitalize FORAGUA, but to finance municipalities' annual investment plans. Interest from FORAGUA's investments is not the main source of project funding; rather, financial sustainability comes from municipalities' environmental fees. Each municipal government has access to the money it collects, minus the ten percent used for FORAGUA's administrative costs. Money not spent on projects is invested by the trust, on behalf of municipal governments, to be spent on future projects. By mid-2012, four of the six member governments had approved investment plans [5]. 
Initially, municipal transfers to FORAGUA were irregular, complicated by difficulties with bureaucracy and political will. A new system was developed in which monthly transfers were automatically made through accounts held by each municipality in Ecuador's Central Bank. By mid-2012, however, only Pindal was still not making regular transfers [6].

One benefit of FORAGUA to municipalities is that it provides a mechanism for soliciting and channeling external donations to member governments. In 2010 and 2011, FORAGUA signed three such contracts [7]. Ecuador's National Water Secretariat (SENAGUA) contributed \$492,000 for reforestation projects in all six member municipalities. The Aquaya Institute contributed $\$ 32,000$ for monitoring municipalities' quality and quantity of water. FONAG and the US Agency for International Development contributed $\$ 35,000$ for a project to strengthen FORAGUA's technical secretariat. Smaller municipalities in particular benefit from the support provided by FORAGUA's technical secretariat since the costs of financing the secretariat fall disproportionately on larger municipalities.

Because FORAGUA is so young, it is difficult to measure its effects. However, there have been increases in the amount of land placed under conservation. When FORAGUA was created, roughly 600 hectares were being protected through land purchases and projects financed by the fund. By 2012 that number had increased to around 3,000 hectares (roughly 2,500 in Loja and 500 in the other municipalities) [6]. In total, more than 20,000 hectares of Reserves have been created through municipal ordinances. As a result of these ordinances and projects, 51 percent of the water catchment areas serving the city of Loja are being protected. These numbers are 21 percent for the city of Celica, 21 percent for the city of Alamor in Puyango, and 11 percent for Macará [8]. FORAGUA is currently working with FONAG and the US Agency for International Development to develop a methodology for measuring the impacts of this conservation. While difficult to measure, the technical staff of FORAGUA and affiliated member governments report changes in local attitudes regarding environmental issues and conservation, particularly among government officials. These issues, which were traditionally seen as unimportant, are now on governments' agendas and are regularly included in planning processes.

\section{Trends in Ecuador's evolving water funds}

Ecuador's newer water funds suggest several possible trends in the financing of watershed conservation within the country. Ecuador is a good place to study this issue because it is the site of two pioneering models of voluntary, decentralized systems for financing the conservation of watershed ecosystems. In 2000, the same year FONAG was established, the municipality of Pimampiro launched one of the world's first voluntary, decentralized PES programs to protect the watershed where its drinking water originates. Just as FONAG's creators (particularly The Nature Conservancy) worked to replicate the water trust fund model, Ecuadorian NGO Cederena worked to establish Pimampiro-style PES programs in municipalities across Ecuador in the mid-2000s. Examples include 
Loja, Celica, Puyango, and Pindal, four of the five founding member governments of FORAGUA.

The differences between the Pimampiro and FONAG models should not be overstated, but there are some important distinctions. The Pimampiro model is closer to a traditional PES scheme. Municipal governments collect a fee levied on water use. This money is held in a bank account, typically managed by the municipal government. Sometimes, a participatory environmental services committee is established to provide public oversight and give the watershed's stakeholders a role in decision-making. However, the municipal government ultimately controls the resources and process. By contrast, water trust funds are managed by an entity that is independent of the local government. While local governments may be members of a trust's governing board, they do not have unilateral control over the funds. Also, the public-private, multi-stakeholder nature of the trust's governing board facilitates greater collaboration among watershed stakeholders.

\subsection{Moving from Pimampiro-style PES toward FONAG-style water funds}

One trend observable in Ecuador over the last decade is the move away from Pimampiro-style PES programs toward FONAG-style water funds. This is most evident in FORAGUA. FORAGUA was created through the joining of municipal governments that had already established Pimampiro-style PES programs, or in the case of Macará, was in the process of establishing one. The process was spurred by Nature and Culture International, which was working with these municipalities to create these PES programs. This accounts for FORAGUA's unusual institutional design. According to Nature and Culture International personnel [9], there were several reasons for incorporating the municipal PES programs into a regional water trust fund. First, the trust provides greater protection against political instabilities plaguing local PES programs, particularly the politicization of programs and the diversion of funds for other purposes. Second, the linking of large and small municipalities strengthens small municipalities' ability to engage in watershed conservation. Individually, small municipalities cannot raise enough money through environmental taxes to engage in meaningful conservation. FORAGUA provides small municipalities with technical support and additional money from interest on investments and outside donations. Third, the trust can facilitate external donations. Many donors are either reluctant or prohibited from providing money directly to government entities. Private trusts provide a mechanism for overcoming these difficulties. For these same reasons, El Chaco, a municipality with one of the country's oldest PES programs, is also planning to convert its watershed management program into one based on a FONAG-style water trust fund [10].

Tungurahua's water fund also emerged from an earlier effort to create a moretraditional PES program. In the late 1990s, GTZ, the Tungurahuan provincial government, and local NGOs CESA and IEDECA were collaborating to promote watershed conservation. GTZ advocated a PES system and, with the provincial government's support, hired a team of Costa Rican experts in 2001 to design such a system. In his keynote speech at the province's first Water Resources 
Forum, held in January 2002, Prefect Fernando Naranjo announced the government's plans to create a PES scheme [11]. The proposal was unveiled at a public assembly in February 2002. The plan called for a tax of two cents per cubic meter of water, which would be used to finance conservation, restoration, and development efforts [12].

Because social groups had voiced their support for watershed management reforms, GTZ and the provincial government were surprised when the proposal was met with fierce resistance. Development NGOs (including CESA and IEDECA), as well as farmer associations and irrigation councils, criticized the plan as unjust. They argued that levying a flat fee on water use would finance the program on the backs of poor farmers, who relied on irrigation. Indigenous groups feared the plan would lead to the privatization and commodification of nature. Given the severity of the backlash, the phrase "payment for ecosystem services" became toxic, and no organization publicly supported such a program.

Interestingly, while indigenous communities living in the páramos opposed a PES program, which they viewed as privatization, they embraced the idea that water users living below should compensate them for protecting and restoring the páramos. Specifically, they demanded resources to enhance agricultural production in lower areas to improve the quality of life in poor communities. The province's participatory Water Parliament became a forum for community members to discuss the idea of getting different water users to voluntarily contribute to a common fund to finance local economic development initiatives and conservation programs. GTZ embraced the idea and worked with The Nature Conservancy to develop a proposal modeled on FONAG. GTZ also negotiated the participation of large water users, including the hydroelectric companies and municipal water company that became founding members. With its voluntary contributions and lack of direct payments to landowners, Tungurahua's water fund fit better with local indigenous priorities regarding community well-being, as well as their concerns about the commodification and privatization of natural resources. Unlike a strict PES scheme, Tungurahua's trust fund does not directly compensate individuals. Rather, it finances a range of activities designed to benefit the ecosystem and the communities that live within them. According to indigenous leaders, this distinction was crucial because it emphasized the public nature of natural resources and the focus on human well-being [13].

In sum, while the evidence is anecdotal, there appears to be a trend away from strict PES programs toward water trust funds within Ecuador. There are several reasons for this. First, water funds are better able to insulate watershed management from local politics. The trust prevents politicians from diverting money for watershed conservation toward other uses. Also, relatively high barriers to exit provide some continuity through changes in administrations and mitigate the effects of clientelistic politics. New mayors often try to abolish and discredit programs of the previous mayor, which can undermine longer-term development efforts. A common feature of Ecuador's water trust funds is that local governments can only withdraw after mayors convene all stakeholders and publicly justify their decision. In two cases (Celica and Quito), new mayors announced their intention to withdraw from their respective water funds 
(FORAGUA and FONAG). However, they reversed their decisions after learning the exit rules. It is impossible to know the reason for their reversals. But it is reasonable to presume their decisions were influenced by the prospect of public shaming for undermining popular norms of sustainable natural resource management for personal political gain.

Second, while trust funds do not preclude direct payments to individuals, they allow for a wider array of activities that occur at the community or watershed level. Some Ecuadorian watershed conservation advocates argue that direct payments fail to instill a sense of value in conservation among those living in watersheds and can lead to blackmail. In some communities, particularly those with a strong indigenous presence, direct cash payments have led to concerns about privatization. By taking a more integrated approach and designing projects at the watershed and/or community levels, trust funds can reinforce the notion of watershed resources being public goods and promote a sense of community responsibility. Third, trust funds' public-private, multi-stakeholder decisionmaking mechanism, along with community-level projects, facilitates greater collaboration. This is consistent with the Ecuadorian tradition of mingas, in which people work collectively on projects that benefit the entire community.

\subsection{Linking with participatory watershed management committees}

Ecuador's evolving water trust fund model seeks to place funds within a watershed management system that includes a local, participatory decisionmaking body independent of these trust funds. While trusts' boards of directors typically include major water users (the main contributors to the funds), other participatory decision-making bodies incorporate a wider array of watershed stakeholders, regardless of whether they are fund members. At a minimum, these participatory bodies provide oversight for water funds, but they often serve as a space for collaboratively setting priorities and developing projects that are later financed through the trust funds. In some instances, they are even given authority to control the transfer of money to the trust funds. This is the case in Celica, a member of FORAGUA, and in Quito, where attempts to develop a watershed council platform are underway (described below).

One example of these participatory bodies is Tungurahua's Water Parliament, created in 2004 as part of the province's New Governance Model. The Water Parliament provides a space for hundreds of public and private actors to specify common objectives, set priorities, formulate proposals, make policy decisions, provide oversight, and form working teams to spur policy implementation. The bulk of activity happens in four working groups oriented around the páramos, irrigation, potable water, and sanitation. A technical unit provides technical and logistical assistance to advance proposals and facilitate institutional coordination. The Water Parliament's páramo working group has been an important space for developing and monitoring the páramo management plans financed by the FMPLPT. The FMPLPT also funds conservation projects developed by irrigation and sanitation councils that participate in the Parliament's other working groups. As a member of the Water Parliament, the FMPLPT's technical secretariat contributes to the Parliament's decision-making and provides technical support. 
In FORAGUA, several member municipalities have Environmental Services Committees that were created as part of their original PES programs. This is particularly true for those programs modeled after the one in Pimampiro (e.g., Celica, Puyango, and Pindal). Whereas municipal governments are the only local representatives on FORAGUA's governing board, these Environmental Services Committees include representatives of local government, water users, landowners living in the watersheds' catchment areas, and other interested parties. Ideally, these committees provide a space for jointly setting priorities, supporting the planning process, and providing oversight. In Celica, for example, the committee has the authority to purchase land for conservation, negotiate compensation for conservation agreements with landowners, hire guards to monitor compliance, and approve financial transfers to FORAGUA.

The trend toward linking trusts with more-participatory watershed management bodies is also illustrated by FONAG. Seven years after its founding, and after a drawn-out fundraising process, FONAG partnered with the Ecuadorian NGO Fundación Futuro Latinoamericano (FFLA) to create a moreparticipatory and integrated approach to watershed management in the Guayllabamba watershed, which feeds Quito. With funding from the InterAmerican Development Bank, in 2008 FFLA began organizing watershed stakeholders with the goal of creating a "Multi-Actor Platform" - a space where stakeholders representing multiple sectors (e.g., energy, irrigation, consumption) and scales (e.g., national, watershed, and sub-watershed) would collaboratively design and implement watershed management plans financed through FONAG [14]. The plan is to create micro-watershed committees to provide participatory planning and implementation processes at the community level. A watershed council will link committees within a given watershed to ensure an integrated approach at the watershed level. Roughly 300 representatives of 120 organizations have participated in related assemblies and workshops [14]. However, the process of creating the Guayllabamba Watershed Council remains a work in progress. This process has been slowed by the national legal and institutional changes resulting from the 2008 Constitution, as well as the continued uncertainty caused by Congress's failure to finalize a new Water Law. Nevertheless, Ecuador's Water Secretariat (SENAGUA) has expressed support for the creation of watershed councils throughout the country, suggesting the trend of linking water funds with local, participatory decision-making bodies may continue.

\subsection{Scaling up from the grassroots}

It is no coincidence that the participatory decision-making bodies described above preceded the creation of the two water funds studied here. Ecuador's newer water funds are being built on social foundations created by years of training and organization around watershed management at the grassroots level. In the cases of FORAGUA and FMPLPT, advocates of watershed conservation worked for years to foster voluntary conservation agreements at the community level before water funds were created. Over time, these community agreements were aggregated to allow for watershed management at a larger scale. Once 
created, the water funds not only provided a financing mechanism, but also a way to link multiple local watershed conservation efforts and take a more integrated approach to watershed management. In this way, Ecuador's newer funds reflect a process of scaling up watershed conservation from the grassroots to the watershed level and beyond. This is clearly seen in the case of FORAGUA, where municipal watershed management programs were combined to take a more integrated approach at the regional level. The scale of watershed management through FORAGUA continues to expand; FORAGUA is currently negotiating with seven additional municipalities interested in joining [6].

The Tungurahuan case also illustrates the scaling up process. Before the FMPLPT was created, local NGOs like CESA and IEDECA spent more than a decade working with communities in the páramos to train local promoters and strengthen civil society organizations dedicated to páramo conservation. Community promoters facilitated the negotiation of voluntary community agreements (Actas de Acuerdo) to conserve strategic areas of these communities' páramos. These communities then began developing plans for managing the páramos sustainably. The first accords and plans were reached in the late 1990s, and the number increased during the 2000s. As described above, these accords and plans have become the basis for the FMPLPT's activities. The increase in the number of páramo management plans financed through the FMPLPT illustrates the scaling up of watershed management activities. Initially, the fund focused on three sections of páramo in the upper Ambato Watershed where community agreements and plans were strongest. By 2010, eight community páramo management plans, covering most of the watershed's catchment areas, were incorporated into the FMPLPT's plans. Since then, the FMPLPT has expanded its projects to include neighboring micro-watersheds, including those for the Pachanlica and Cutuchi rivers.

The scaling up of watershed management programs has greatly facilitated the ability of Ecuador's new water funds to collaborate with local communities and contributes to the funds' effectiveness. These funds are reliant on local actors for their participation in all stages of watershed conservation and management, from agreements to conserve and restore catchment areas to monitoring and sanctioning those who violate the agreements. Local communities each set and enforce their own penalties for burning páramo, deforesting, or placing animals in protected areas. Sanctions include fines and the confiscation of animals. The role of local actors in designing, implementing, monitoring, and enforcing watershed management plans illustrates the significant changes in communitylevel watershed management underway in Ecuador. As described above, the country's water funds are both affected by and contribute to these changes.

\subsection{Investing early in conservation projects}

Ecuador's newer funds differ from FONAG in that a portion of their assets are spent on watershed conservation projects rather than invested to grow the fund. By contrast, FONAG only spends the financial returns from the trust's investments; the trust's assets remain untouched to ensure the sustainability of financial resources. The decision whether or not to spend a trust's assets on 
projects involves a tradeoff. Not touching these assets allows a fund to grow more rapidly, lessening the time before the interest on investments provides a sustainable revenue stream large enough to finance conservation. However, this can mean waiting years before financing conservation. Unable to see tangible results, water users and other stakeholders may become disillusioned with the process. Spending part of a fund's assets on conservation and related projects can produce short-term effects that give water users an incentive to support the fund. But this lengthens the time before the interest on investments provides a sustainable revenue stream.

FONAG focused on growing its assets, and it was four years before it began investing in watershed conservation. During this time FONAG received criticism because an important amount of money was going to the fund, but the impact on conservation was small. From FONAG's experience, Ecuador's newer funds learned the importance of funding projects in the short-term to maintain credibility with local stakeholders. For this reason, a trend among newer water funds is to split the use of assets between capitalization and projects. In Tungurahua's fund, 60 percent of member contributions are invested to grow the trust while 40 percent are spent on projects. In FORAGUA, only members' initial transfers were used to capitalize the fund. All subsequent contributions are used to finance projects.

\section{Conclusion}

The growing number of water trust funds in Ecuador and beyond suggests these funds offer many advantages for financing watershed conservation. Ecuador's water funds are evolving within the context of broader changes in communitylevel watershed management around the country. These funds are emerging from longer-term processes of building integrated watershed management systems at the local level. The differences between FONAG and later funds reflect lessons learned through these processes. These funds are also contributing to and shaping these processes. Their effects can be seen in the various projects being financed through the funds - educating citizens to create a culture of conservation; training local professionals to build communities' capacity for watershed conservation; improving the efficiency of agricultural production and expanding access to markets in order to compensate communities for the costs of conservation; providing an institutional space for collaborative decision-making among multiple stakeholders at multiple scales; gathering scientific information to improve decision-making; and providing a sustainable financing mechanism.

\section{Acknowledgement}

We thank Ana Belen Espinoza for her research support and assistance with interviews conducted for this study. 


\section{References}

[1] Goldman, R.L., Benitez, S., Calvache, A. \& Ramos, A., Water funds: Protecting watersheds for nature and people, Arlington, Virginia: The Nature Conservancy, 2010.

[2] Creating Water Funds for People and Nature; The Nature Conservancy, Online. www.nature.org/ourinitiatives/regions/latinamerica/water-fundsof-south-america.xml

[3] Rojas, O., "Informe de Gestión Febrero 2012," Ambato, Ecuador: Fideicomiso Fondo de Páramos Tungurahua y Lucha Contra la Pobreza, Marzo de 2012.

[4] Rojas, O., Personal communication, 4 July 2012, Technical Secretary, Fund for Páramo Management and Fight Against Poverty in Tungurahua, Ambato, Ecuador.

[5] Rengel, E., "Informe Rendición de Cuentas," Loja, Ecuador: Secretaria Técnica, Fondo Regional del Agua, Abril 2012.

[6] Rengel, E., Personal communication, 29 June 2012, Technical Secretary, Regional Water Fund, Loja, Ecuador.

[7] Reunión de la Junta de Directorio de FORAGUA, FORAGUA - El Fondo Regional del Agua, Online. www.foragua.org/noticias reuniondirectorio-2011.html

[8] FORAGUA, www.foragua.org/

[9] Rodas, F., Personal communication, 20 January 2010, Cuenca Region Coordinator, Nature and Culture International, Loja, Ecuador.

[10] Zarria, E., Personal communication, 20 April 2010, Director of Environmental Management, Municipal Government of El Chaco, El Chaco, Ecuador.

[11] Documento Final: Recopilación detallada de Talleres Provinciales, Entrevistas, Foro Provincial y Mesas de Trabajo, Foro Provincial de los Recursos Hídricos en Tungurahua, Ambato, Ecuador: Consorcio CAMAREN, 2002.

[12] Comisión Ejecutiva Provincial, Propuesta Para la Implementación del Pago por Servicio Ambiental Hídrico en la Provincia de Tungurahua y su Aplicación en una Zona Piloto, Ambato, Ecuador: Honorable Gobierno Provincial de Tungurahua, 2002.

[13] Moreta, C., Personal communication, 18 November 2009, Former President, Indigenous Movement of Tungurahua-Atocha (MITA), Ambato, Ecuador.

[14] Cabrera, P. Sistematización del Proceso de Gobernanza Interescalas para la Gestión de los Recursos Hídricos. El caso de la Cuenca Alta del Río Guayllabamba, Quito, Ecuador: Fundación Futuro Latinoamericano (FFLA), 2011. 